\title{
T-Box Transcription Factor TBX1
}

National Cancer Institute

\section{Source}

National Cancer Institute. T-Box Transcription Factor TBX1. NCI Thesaurus. Code C75413.

T-box transcription factor TBX1 (398 aa, 43 kDa) is encoded by the human TBX1 gene.

This protein plays a role in transcriptional regulation and embryonic development. 